ノート

切断麦に適しポリフェノール含量が極低く炊飯後褐変が少ない六条皮麦新品種 「はるしらね」の育成

青木恵美子 ${ }^{1)}$ ・塔野岡卓司 ${ }^{1,2)}$ ・吉岡藤治 ${ }^{1,3)}$ ・河田尚之 ${ }^{1,2)}$ ・吉田めぐみ ${ }^{1,4)}$

1) 作物研究所, つくば市, $=305-8518$

2) 現 : 九州沖縄農業研究センター筑後研究拠点，筑後市，＝ 833-0041

3) 現 : 近畿中国四国農業研究センター, 善通寺市, $\mathbf{T} 765-8508$

4) 現：農林水産省農林水産技術会議事務局，東京都千代田区， $\overline{1} 100-8950$

\title{
Breeding of a new six-rowed hulled barley cultivar "Harushirane" with proanthocyanidin-free gene
}

Emiko Aoki ${ }^{1)}$, Takuji Tonooka ${ }^{1,2)}$, Toji Yoshioka ${ }^{1,3)}$, Naoyuki Kawada ${ }^{1,2)}$ and Megumi Yoshida ${ }^{1,4)}$

1) NARO Institute of Crop Science, Tsukuba 305-8518, Japan

2) Present address: Lowland Farming Research Station, NARO Kyushu Okinawa Agricultural Research Center, Chikugo 833-0041, Japan

3) Present address: NARO Western Region Agricultural Research Center, Zentsuji 765-8508, Japan

4) Present address: Agriculture, Forestry and Fisheries Research Council Secretariat, Ministry of Agriculture, Forestry and Fisheries, Tokyo 100-8590, Japan

キーワード

オオムギ，加熱後褐変，精麦，切断麦，プロアントシアニジンフリー

\section{1. 育成の背景}

主食用の大麦は押麦や切断麦に加工されて年間約 5 万 トンが麦ご飯として利用されているが，国内生産量は需 要量を下回って扣り，主食用大麦の国内産麦使用率は約 $83 \%$ となっている（中山 2010）。このため，精麦業界か らは国産の主食用大麦の生産拡大と安定供給を強く要望 されている。

しかし, 一般的に大麦は小麦と比べて収益性が低いこ とから，国内生産量は頭打ち状態である。そこで，安定 多收品種や栽培技術の導入による生産性の向上に加えて, 炊飯後の褐変や食味の改善, 機能性成分を多く含有寸る といった高付加価值化による収益性の向上によって生産 者の作付け意欲を喚起することも重要である.

大麦は炊飯等の加熱処理により褐変を生じ，見た目が 悪くなりやすく，このことが大麦の消費拡大の妨げの一 つとなっている．大麦の穀粒には米や小麦と比べてポリ フェノール成分が多く含まれているが (Dykes and Rooney 2007, Hodzic et al. 2009)，ポリフェノール含量と加熱後褐変 との間に高い相関があり（神山・藤田 2000, 藤田ら 2000), ポリフェノール成分の中でも (+)- カテキンやプロアント シアニジンが加熱後褐変への影響が大きいことが報告さ

編集委員 : 北野英己

2013 年 2 月 28 日受領 2013 年 8 月 17 日受理

Correspondence: emikonk@affrc.go.jp
れている (Kohyama et al. 2009). 大麦ではプロアントシ アニジンの生合成が遺伝的に阻害される突然変異遺伝子 であるプロアントシアニジンフリ一遺伝子 (ant) が単離 されて打り，現在 ant $13 ， 17 ， 18 ， 19 ， 21 ， 22 ， 25 ， 26$, $27,28,29,30$ の 12 の遺伝子座が報告されている (JendeStrid et al. 1999). ant 遺伝子を有する突然変異系統ではプ ロアントシアニジンとカテキン含量が極めて少なく（藤 田ら 2000)，ポリフェノール含量の割に加熱後褐変しに くい(神山・藤田 2000)，そこで， ant 遺伝子を利用する ことで，プロアントシアニジンを殆ど含まず，炊飯等の 加熱処理によっても褐変しにくく白さを保つ「極低ポリ フェノール大麦」品種の育成が進められてきた. とくに, ant 28 を有する系統が農業特性の点から有望であると考 えられ (長嶺ら 2006), ant28.494 の遺伝子を導入し, 加 熱後褐変が極めて少ない極低ポリフェノール大麦として 「とちのいぶき」(高山ら 2011), 「白妙二条」(Tonooka et al. 2010)，「キラリモチ」（Yanagisawa et al. 2010）が育成 され，精麦業界から高い評価と期待を得てきている.

しかし，これらの品種はいずれも二条大麦で大粒であ り，千粒重が大きいと砕粒率が高くなることが報告され ていると打り（塔野岡ら 2010, 沖山ら 2012），粳性であ る「とちのいぶき」、「白妙二条」では，搗精加工時に割 れやすいことが指摘されている，現在，麦ご飯用製品の らち，黒条線に沿って麦粒を切断する切断麦・米粒麦が 約 7 割を占め, 切断性に優孔て砕粒が少ないことが極低 ポリフェノール大麦に打いても望まれていた。 
このよらな背景の中, 作物研究所では, 炊飯後に褐変 しにくい極低ポリフェノール大麦で，切断麦・米粒麦な ぞにも適性を有する六条大麦品種「はるしらね」を育成 した。「はるしらね」は収量性が高く, オオムギ縞萎縮病 に抵抗性を有することから, 主食用大麦の安定生産に貢 献することが期待できる，ここでは，「はるしらね」の育 成経過と品種特性について報告する.

\section{2. 育成の経過}

「はるしらね」は, 2001 年度（2002 年 4 月, 以下播種 年度で示す）に，作物研究所（茨城県つくば市）に打い て, 軟質・高白度で精麦品質が優れる「東山皮 96 号（後 のファイバースノウ)」に, 二条大麦の系統でプロアント シアニジン欠失遺伝子 (ant28.494) を有する「泉系 A133$3 」$ を交配した雑種第 1 代 $\left(F_{1}\right)$ を母親, 早生・短強秙・ オオムギ縞萎縮病抵抗性で精麦品質が優れる「東山皮 101 号（後のシルキースノウ）」を父親として人工交配を行 い，系統育種法により育成された（図 1).2003 年度に固 場での個体選抜 $\left(\mathrm{F}_{2}\right)$ を行い, さらにバニリン呈色の有 無により,プロアントシアニジン欠失の特性を持つ ant 28 型個体を選抜した。 2004 年度 $\left(\mathrm{F}_{3}\right)$ から系統の育成と選 抜を行った。 2005 年度 $\left(\mathrm{F}_{4}\right)$ から生産力検定予備試験お よび特性検定試験に供試し，2006 年度 $\left(\mathrm{F}_{5}\right)$ からは「関 系b536」の系統名を付して系統適応性検定試験に供試し た.これら一連の試験により，収量性やオオムギ縞萎縮 病やらどんこ病への抵抗性等の栽培特性が優れており, 炊飯麦の加熱後褐変を殆ど生じないことを確認したので, 2007 年度 $\left(\mathrm{F}_{6}\right)$ から「関東皮 88 号」の系統名を付して,

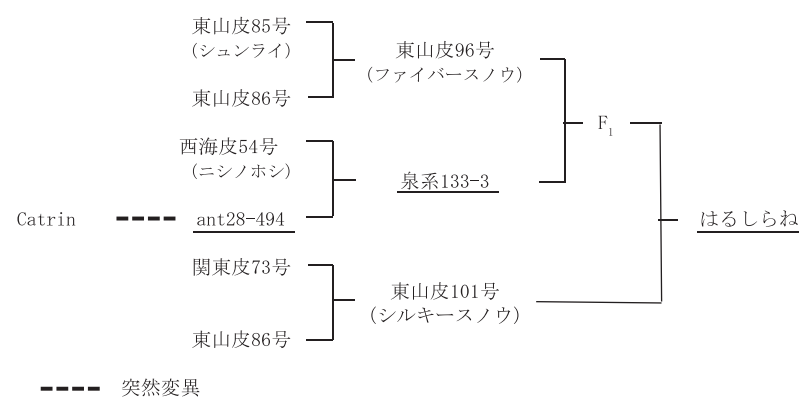

図 1.「はるしら対」の育成系譜

下線を付した品種・系統は ant28.494 遺伝子を持つことを 示す.
奨励品種決定調査に供試した. 2010 年に切断麦適性があ り加熱後褐変が小さい極低ポリフェノール含量の大麦新 品種「はるしらね」として品種登録出願を行い（出願日 2010 年 1 月 8 日. 出願番号第 24501 号), 2012 年 8 月 22 日に登録された（登録番号第21879号）。

\section{3.「はるしらね」の特性}

\section{1）形態的·生態的特性}

株・穂・子実の形態を図 2 に, 生育調査と収量試験結 果を表 1 に示す．比較品種として，六条皮麦で主に精麦 用として利用されている「シュンライ」と「シルキース ノウ」を供試した.

「はるしらね」は並性の六条皮麦である。秋播性程度は IVで秋播型である. 出穂期は「シュンライ」より 5 日程 度早く,「シルキースノウ」と同程度の “やや早生” であ る. 成熟期は「シュンライ」と「シルキースノウ」並み の “やや早生”である. 秙長は「シュンライ」と同程度 であるが，「シルキースノウ」より長い、穂長は「シュン ライ」よりやや長く,「シルキースノウ」並である. 穂数 は比較 2 品種と同程度で, 収量性は比較 2 品種並に高い. 千粒重は比較 2 品種よりも軽く, 容積重は「シュンライ」 より重く,「シルキースノウ」と同程度である. 整粒歩合 は比較 2 品種と同程度である.

病害抵抗性と障害抵抗性を表 2 に示す。「はるしらね」 はオオムギ縞萎縮病 I ・II・III型系統とらどんこ病に抵
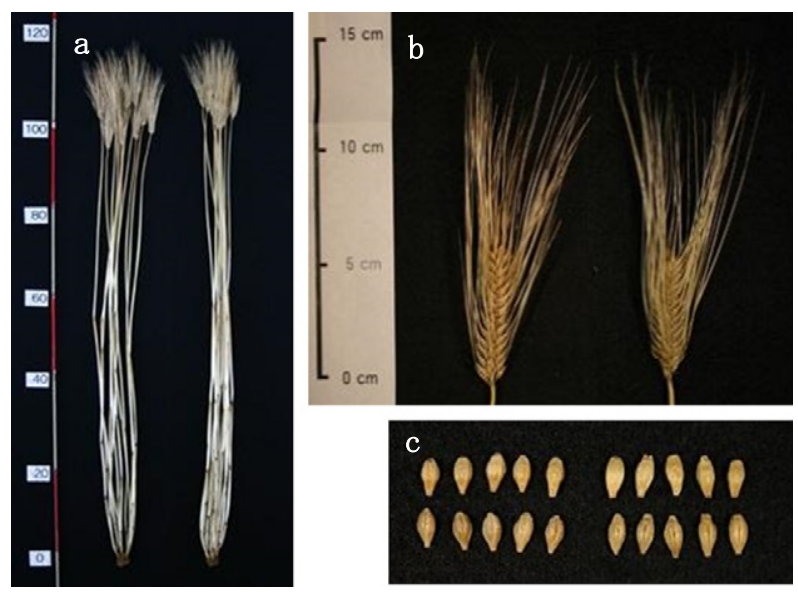

図 2.「はるしら祄」の株（a)，穂（b)，子実（c） 左：はるしら㸚 右：シュンライ

表 1. 育成地における「はるしらね」の生育および収量試験結果 ${ }^{1)}$

\begin{tabular}{cccccccccccc}
\hline \hline \multirow{2}{*}{ 品種名 } & $\begin{array}{c}\text { 秋播性 } \\
\text { 程度 }\end{array}$ & $\begin{array}{c}\text { (月.日穂期 } \\
(\text { 月.日成熟期 } \\
(\text { 月.日 })\end{array}$ & $\begin{array}{c}\text { 㷏長 } \\
(\mathrm{cm})\end{array}$ & $\begin{array}{c}\text { 穂長 } \\
(\mathrm{cm})\end{array}$ & $\begin{array}{c}\text { 穂数 } \\
\left(\text { 本 } / \mathrm{m}^{2}\right)\end{array}$ & $\begin{array}{c}\text { 収量 } \\
(\mathrm{kg} / \mathrm{a})\end{array}$ & $\begin{array}{c}\text { 容積重 } \\
(\mathrm{g} / \mathrm{L})\end{array}$ & $\begin{array}{c}\text { 千粒重 } \\
(\mathrm{g})\end{array}$ & $\begin{array}{c}\text { 整粒歩合 } \\
(\%)\end{array}$ & $\begin{array}{c}\text { 原麦外観 } \\
\text { 品質 }{ }^{3)}\end{array}$ \\
\hline はるしらね & $\mathrm{IV}$ & $4.15 \mathrm{a}$ & $5.30 \mathrm{a}$ & $98.7 \mathrm{~b}$ & $5.4 \mathrm{~b}$ & $662 \mathrm{a}$ & $67.8 \mathrm{a}$ & $705 \mathrm{~b}$ & $29.3 \mathrm{a}$ & $79.7 \mathrm{a}$ & $5.3 \mathrm{a}$ \\
シュンライ & $\mathrm{I}$ & $4.20 \mathrm{~b}$ & $5.30 \mathrm{a}$ & $99.1 \mathrm{~b}$ & $5.0 \mathrm{a}$ & $612 \mathrm{a}$ & $63.4 \mathrm{a}$ & $680 \mathrm{a}$ & $31.2 \mathrm{~b}$ & $80.1 \mathrm{a}$ & $5.2 \mathrm{a}$ \\
シルキースノウ & $\mathrm{IV}$ & $4.15 \mathrm{a}$ & $5.30 \mathrm{a}$ & $88.4 \mathrm{a}$ & $5.6 \mathrm{~b}$ & $596 \mathrm{a}$ & $68.6 \mathrm{a}$ & $696 \mathrm{~b}$ & $31.3 \mathrm{~b}$ & $81.0 \mathrm{a}$ & $5.4 \mathrm{a}$ \\
\hline
\end{tabular}

1) 畑ドリル標肥栽培における 2006〜2011 年度の平均值. 異なる文字を付した数值には $5 \%$ 水準で有意差あり (Tukey 法).

2) 粒厚 $2.2 \mathrm{~mm}$ 以上の整粒の割合.

3) 1 : 上上〜 9 : 下下の 9 階級評価. 
表 2.「はるしら社」の病害抵抗性および障害抵抗性 ${ }^{11}$

\begin{tabular}{|c|c|c|c|c|c|c|c|c|}
\hline \multirow{2}{*}{ 品種名 } & \multicolumn{3}{|c|}{ オオムギ縞萎縮病 } & \multirow{2}{*}{$\begin{array}{c}\text { 麦類萎 } \\
\text { 縮病 }\end{array}$} & \multirow{2}{*}{$\begin{array}{c}\text { らどんこ } \\
\text { 病 }\end{array}$} & \multirow{2}{*}{$\begin{array}{c}\text { 赤かび } \\
\text { 病 }\end{array}$} & \multirow{2}{*}{$\begin{array}{c}\text { 耐倒伏 } \\
\text { 性 }\end{array}$} & \multirow{2}{*}{$\begin{array}{c}\text { 穂発芽 } \\
\text { 性 }\end{array}$} \\
\hline & I 型 & II型 & III型 & & & & & \\
\hline はるしらね & 極強 & 極強 & 極強 & 中 & 極強 & やや弱 & やや強 & やや易 \\
\hline シュンライ & やや強 & やや強 & やや強 & 弱 & やや弱 & やや弱 & 強 & 難 \\
\hline シルキースノウ & 極強 & 極強 & 極強 & 弱 & 中 & やや弱 & やや強 & 極難 \\
\hline
\end{tabular}

1) 2006 ～ 2008 年度の特性検定試験および生産力検定試験における成績により判定. ただし麦類萎縮病は 2010, 2011 年度の結果を基に判定した.

表 3.「はるしらね」の精麦品質1)

\begin{tabular}{|c|c|c|c|c|c|c|}
\hline 品種 & 試験年度 & 条性 & $\begin{array}{l}\text { 搗精時間 } \\
(\text { (秒) }\end{array}$ & $\begin{array}{c}\text { 精麦白度 } \\
(\%)^{3)}\end{array}$ & $\begin{array}{l}\text { 砕粒率 } \\
(\%)^{4)}\end{array}$ & 粒質 5) \\
\hline はるしらね & \multirow{3}{*}{$2006 \sim 2010$} & 6 & $549 \mathrm{a}$ & $45.2 \mathrm{a}$ & $5.9 \mathrm{~b}$ & $3.8 \mathrm{ab}$ \\
\hline シュンライ & & 6 & $561 \mathrm{a}$ & $45.2 \mathrm{a}$ & $2.5 \mathrm{a}$ & $5.0 \mathrm{~b}$ \\
\hline シルキースノウ & & 6 & $570 \mathrm{a}$ & $48.4 \mathrm{~b}$ & $3.0 \mathrm{a}$ & $3.6 \mathrm{a}$ \\
\hline \multirow{2}{*}{$\begin{array}{l}\text { はるしらね } \\
\text { ミカモゴールデン }\end{array}$} & \multirow{2}{*}{$2006 \sim 2009$} & 6 & $517 \mathrm{~b}$ & $46.0 \mathrm{a}$ & $6.3 \mathrm{a}$ & $3.5 \mathrm{a}$ \\
\hline & & 2 & $389 \mathrm{a}$ & $46.6 \mathrm{a}$ & $9.3 \mathrm{a}$ & $4.9 \mathrm{a}$ \\
\hline
\end{tabular}

1) 水田慣行条播標肥栽培における平均值. 異なる文字を付した数值には $5 \%$ 水準で有意差あり（上段は Tukey 法，下段は t 検定による).

2) 試験搗精機（佐竹 TM-05 型）を使用し，整粒 $180 \mathrm{~g}$ につて 55\% 歩留まで搗精するのに要した時間.

3) $55 \%$ 歩留精麦について光電白度計（ケット C-300）で測定.

4) $55 \%$ 歩留精麦 $10 \mathrm{~g}$ 中の欠損粒の重量比.

5) 2 : 完全な粉状質, 3 : 粉状質, 4 : やや粉状質, 5: 中間質, 6: やや硝子質, 7 : 硝子質, 8 : 完全な 硝子質の 7 階級評価.

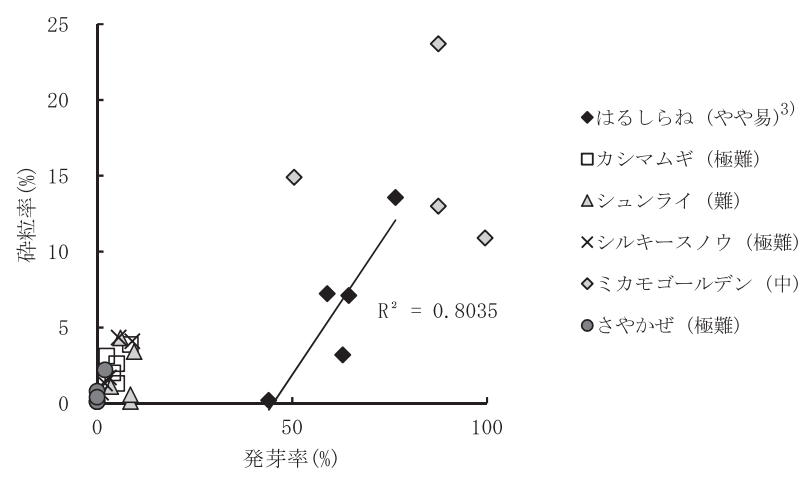

図 3. 成熟期の種子休眠性 ${ }^{1)}$ と搗精時の砕粒率 2 ) との関係 1)成熟期にサンプリングした種子のシャーレに和ける発 芽率 $\left(18^{\circ} \mathrm{C} ， 5\right.$ 日間). $2006 \sim 2010$ 年度 (ミカモゴール デンは2006〜2009 年度) のデータ.

2)烟ドリル標肥栽培生産物に叔ける确粒率.

3) 括弧内は各品種の穂発芽性を示す.

抗性を示す．近年発生が拡大している麦類萎縮病につい ては，比較品種と同様に罹病する．開花受粉性で，赤か び病には比較品種と同様に感染しやすい，程長は「シュ ンライ」と同程度であるが，耐倒伏性は「シュンライ」 よりやや劣る.他の極低ポリフェノール大麦品種と同様 に穗発芽耐性が弱く，穂発芽性は“やや易”である.

\section{2）品質特性}

「はるしら衫」の精麦品質を表 3 亿示す。 $55 \%$ 搗精に 要する時間は「シュンライ」と「シルキースノウ」並で ある. 精麦白度は「シュンライ」並であるが，「シルキー スノウ」よりはやや劣る. 搗精時の粒質は「シュンライ」
よりやや優れ，「シルキースノウ」と同程度でやや粉状質 である。「はるしら齐」の砕粒率は，年次による変動がや や大きく,「シュンライ」と「シルキースノウ」の砕粒率 より高いが, 4 カ年平均で二条大麦の「ミカモゴールデ ン」と比べると确粒率はやや低い.「はるしら将」は穂発 芽耐性が弱いが，成熟期に拈ける種子休眠性が弱くて発 芽率が高い時には，捣精時の砕粒率が高い傾向が見られ た（図 3)。このため, 緑芽が見られなくても軽度の穂発 芽が生じている時には, 肧乳の分解が進み, 搗精時に砕 粒が多くなると考光られる，極低ポリフェノール育成系 統では穂発芽耐性が従来品種よりも劣ることが指摘され ているが (長嶺ら 2006, Tonooka et al. 2010, 高山ら 2011, Yanagisawa et al. 2011), 搗精時の砕粒を少なくする点か らも收穫時の刈り遅れに注意することが重要である.

ポリフェノール含量の分析結果を表 4 に示した. 「はる しら㸚」のポリフェノール含量は, 原麦拈よび捣精麦で いずれも比較品種である「シュンライ」と「シルキース ノウ」に比べて少なく, 特に加熱後褐変の原因であるプ ロアントシアニジンとカテキンの含量が極めて低い. 炊 飯後の加熱後色相の変化を図 4 に, 写真を図 5 に示した. 「はるしら齐」は, 比較 2 品種と比べて炊飯直後の炊飯麦 の明度 $\left(\mathrm{L}^{*}\right)$ と白度 $(\mathrm{W})$ が高く, 赤み $\left(\mathrm{a}^{*}\right)$ の值が低 かった. 比較品種では, 炊飯後 24 時間保温すると褐変の 指標となる赤久 $\left(\mathrm{a}^{*}\right)$ の值が高くなり, 明度 $\left(\mathrm{L}^{*}\right)$ と白 度（W）の值は低下した。「はるしら衫」の数值の変化は 比較品種と比べて小さく, 赤み $\left(\mathrm{a}^{*}\right)$ の值が低くて加熱 後の褐変が生じにくく, 白度も高く色相は比較品種より 優れている. 黄色みを示す $\mathrm{b}^{*}$ の值は炊飯直後, 24 時間 
表 4.「はるしらね」のポリフェノール含量 ${ }^{1)}$

\begin{tabular}{|c|c|c|c|c|}
\hline \multirow[b]{2}{*}{ 品種 } & \multicolumn{2}{|r|}{ 原麦 } & \multicolumn{2}{|c|}{$55 \%$ 歩留精麦 } \\
\hline & $\begin{array}{c}\text { 総ポリフェ } \\
\text { ノール22) } \\
(\mathrm{mg} / \mathrm{g})\end{array}$ & $\begin{array}{c}\text { プロアントシアニジン } \\
+ \text { カテキン }{ }^{2)} \\
(\mu \mathrm{g} / \mathrm{g})\end{array}$ & $\begin{array}{l}\text { 総ポリフェ } \\
\text { ノール }(\mathrm{mg} / \mathrm{g})\end{array}$ & $\begin{array}{c}\text { プロアントシアニジン } \\
+ \text { +カテキン }(\mu \mathrm{g} / \mathrm{g})\end{array}$ \\
\hline はるしらね & $1.33 \mathrm{a}$ & $2.1 \mathrm{a}$ & $0.37 \mathrm{a}$ & $0.5 \mathrm{a}$ \\
\hline シュンライ & $2.46 \mathrm{~b}$ & $198.7 \mathrm{~b}$ & $0.62 \mathrm{~b}$ & $42.5 \mathrm{~b}$ \\
\hline シルキースノウ & $2.43 \mathrm{~b}$ & $206.8 \mathrm{~b}$ & $0.57 \mathrm{~b}$ & $38.8 \mathrm{~b}$ \\
\hline
\end{tabular}

1) 2006 ～ 2008 年度の平均值 (水田慣行条播標肥栽培). 異なる文字を付した数值には $5 \%$ 水準で有意差あ り (Tukey 法).

2) 原麦または $55 \%$ 歩留精麦を粉砕器 (サイクロテック) で粉砕後, メタノール抽出した上澄液を試料とし て比色定量した. 全ポリフェノール含量はプルシアンブルー法により, プロアントシアニジン+カテキ ン含量は DMACA 法により，カテキン当量で算出した.
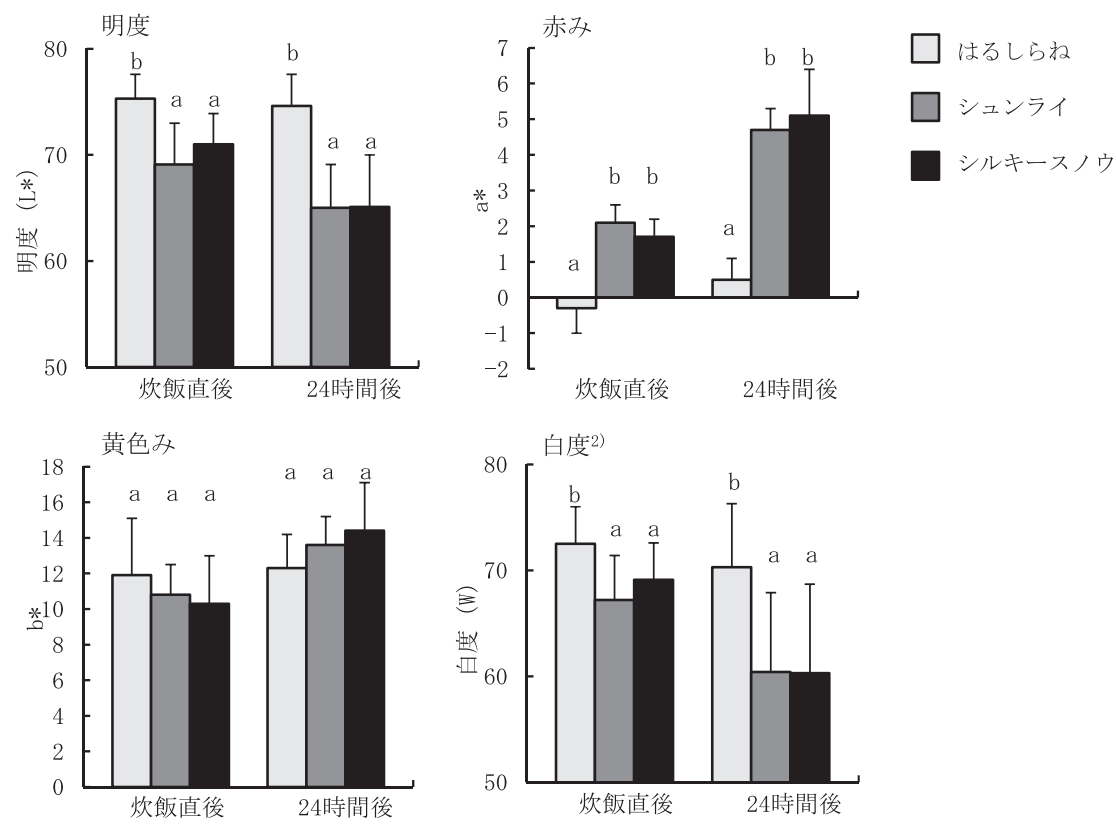

図 4. 炊飯麦の色相変化 ${ }^{1)}$

1) 2006 ２008 年度水田条播栽培の $55 \%$ 歩留精麦 $15 \mathrm{~g}$ に蒸留水 $33 \mathrm{ml}$ を加光, $105^{\circ} \mathrm{C}$ の定温器で 2 時間炊飯し た直後の色相と, 炊飯後 $70{ }^{\circ} \mathrm{C} て ゙ 24$ 時間保温した後の色相について, それぞれ凍結乾燥した粉砕試料 $2 \mathrm{~g} に$ 蒸留水 $14 \mathrm{ml}$ を加光, ペーストにしてから色彩色差計（ミノルタ CM-3500d）で測定した. 異なる文字を付 した数值には $5 \%$ 水準で有意差あり（Tukey 法）.

2) 白度 (W) は以下の式から求めた. $\mathrm{W}=100-\left((100-\mathrm{L} *)^{2}+\mathrm{a}^{* 2}+\mathrm{b}^{* 2}\right)^{1 / 2}$

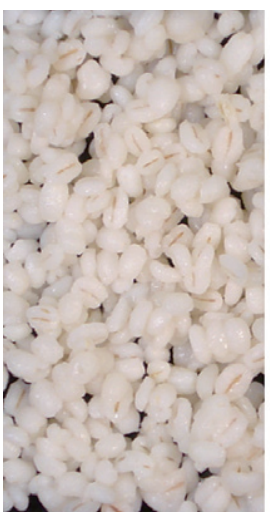

はるしらね

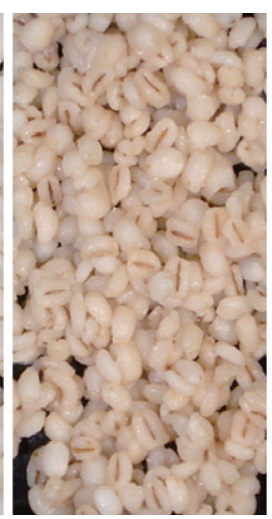

シュンライ

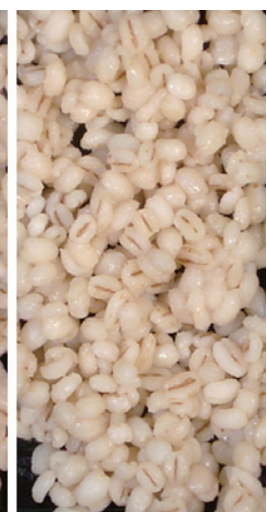

シルキースノウ

図 5. 炊飯麦の保温 24 時間後の色相 2007 年産の水田条播栽培材料を, $105^{\circ} \mathrm{C}$ で 2 時間炊飯し, $70{ }^{\circ} \mathrm{C}$ で 24 時間保温後の褐変程度.

後に扮いても品種による差はなかった。

極低ポリフェノール大麦は精麦業界からの要望が極め て高く，押麦だけでなく，切断麦・米粒麦にも適する「は るしらね」は，家庭利用だけでなく外食産業への普及が 期待されている。 また，麦ご飯の他にも今までは色相の 問題であまり利用されていなかった大麦粉, レトルト食 品, スープの具材やサラダへのトッピング等に用途の拡 大を可能にすると考えられ，食物繊維が豊富な健康食材 である大麦の新規需要が期待される.

\section{謝 辞}

本品種の育成に当たり, 中央農業総合研究センタ一研 究支援センター（業務 1，2，3 科）職員には栽培管理業 務でご尽力いただいた. また，作物研究所麦研究領域麦 
育種分野の契約職員には品質分析に従事していただいた. 関係各位には本品種の育成に多大な貢献をいただき，深 く感謝の意を表する

本品種の育成は，農林水産省「先端技術を活用した農 林水産研究高度化事業」に括ける成果である.

\section{引用文献}

Dykes, L. and L.W. Rooney (2007) Cereal Foods World 52: 105-111. 藤田雅也・武田和義・神山紀子・土門英司・土井芳憲 $(2000)$ 四 国農試報 65: 9-16.

Hodzic, Z., H. Pasalic, A. Memisevic, M. Srabovic, M. Saletovic and M. Poljakovic (2009) Eur. J. Sci. Res. 28: 471-477.

Jende-Strid, B., U. Lundqvist and J.D. Franckowiak (1999) Barley Genet. Newsl. 29: 80-99.

神山紀子・藤田雅也（2000）四国農試報 65: 1-7.

Kohyama, N., M. Fujita, H. Ono, M. Ohnishi-Kameyama, H.
Matsunaka, T. Takayama and M. Murata (2009) J. Agric. Food Chem. 57: 6402-6407.

長嶺 敬・山口恵美子・大関美香・関和孝博・渡邊修孝・渡邊浩 久 $\cdot$ 大野か扣り・条川晃伸・望月哲也・河田尚之, 他 (2006) 栃木農試研報 58: 79-86.

中山則和 (2010) 米麦改良 8: 8-14.

沖山 毅・山口昌宏 - 五月女敏範・長嶺 敬・河田尚之・高山敏 之（2012）日作紀 81: 292-298.

高山敏之 ・五月女敏範 $\cdot$ 大関美香 $\cdot$ 春山直人 $\cdot$ 山口昌宏 $\cdot$ 沖山 毅・長嶺 敬・加藤常夫・渡邊浩久 $\cdot$ 大野か扣り, 他 (2011) 杤木農試研報 66: 53-66.

塔野岡卓司・河田尚之・吉岡藤治・乙部千雅子 (2010) 日作紀 79: 296-307.

Tonooka, T., N. Kawada, M. Yoshida, T. Yoshioka, S. Oda, K. Hatta, T. Hatano, M. Fujita and K. Kubo (2010) Breed. Sci. 60: 172176.

Yanagisawa,T., T. Nagamine, A. Takahashi, T. Takayama, Y. Doi, H. Matsunaka and M. Fujita (2011) Breed. Sci. 61: 307-310. 